\title{
DISRUPTIVE LEADERSHIP IN LEGAL EDUCATION
}

\author{
Nicholas A. Mirkay \& Palma Joy Strand*
}

\begin{abstract}
* Director of Faculty Research, Carlsmith Ball Faculty Scholar and Professor of Law, University of Hawai' i Richardson School of Law, B.S.B.A. Saint Louis University (1989), J.D. University of Missouri (1992), LL.M. Georgetown University Law Center (1996); Professor of Law and Director, 2040 Initiative, Negotiation and Conflict Resolution Program, Department of Interdisciplinary Studies, Creighton University, B.S. Stanford University (1978); J.D. Stanford Law School (1984); LL.M. Georgetown University Law Center (2006). We thank colleagues, past and present, who reviewed and commented on this essay.
\end{abstract}




\section{ABSTRACT}

Legal education and the legal profession are ripe for disruption. The crisis in legal education reflects an increasing mismatch between the limited services that the law and lawyers provide and the vast and acute societal need for legal services. The structure of academia generally and legal academia in particular, however, serves as an obstacle to the disruptive leadership that can initiate necessary adaptation. Here, we discuss our own experience with disruptive leadership and the backlash we received, as well as the risks of failing to embrace disruptive leadership in legal education going forward.

"The act of leadership is not always comfortable."1

\section{INTRODUCTION}

Last spring, the Wall Street Journal unveiled "The Captain Class," a new feature focusing on "the lessons and strategies of leadership." The inaugural column, by reporter Sam Walker, focused on leadership changes at Boeing over the last decade when its Board of Directors intentionally hired Jim McNerney, a "disruptive leader," to redirect the company's trajectory. ${ }^{3}$ "The company had been floundering, and the digital revolution was barging down the gangway." The landscape for Boeing's business had transformed, and Boeing needed to adapt.

Disruptive leaders who reorient institutional culture, Walker observed, necessarily "embrace conflict, are ruthlessly direct and intellectually irreverent." Theoretically there is a "gradual way to renovate a proud old institution," but change rarely unfolds that way. ${ }^{6}$ Rather, "[h]istory shows that it

\footnotetext{
${ }^{1}$ Sam Walker, One Leader Sent Boeing Into a Hurricane; Landing It Was the Next Guy's Job, WALL STREET J. (Apr. 27, 2018), https://www.wsj.com/articles/oneleader-sent-boeing-into-a-hurricane-landing-it-was-the-next-guys-job-1524821400.

${ }^{2}$ Id.

${ }^{3} I d$.

${ }^{4} I d$.

${ }^{5} I d$.

${ }^{6} I d$.
} 
usually comes down to one determined individual - someone who bursts through the door swinging a 7-iron."

While neither of us regularly swings a 7-iron, to our own surprise we recognized ourselves in the description of disruptive leaders prodding a proud old institution to evolve to meet a changing environment. Two years ago, both of us were full, tenured professors at the Creighton University School of Law. We sought to position the law school as a leader in responding to the shifting and uncertain landscape that currently characterizes law, the legal profession, and legal education. Because of institutional resistance to change, however, neither of us remains in our former positions. One of us is now a tenured Professor of Law at the University of Hawai $i$ Richardson School of Law; the other is still at Creighton and still a tenured Professor of Law, but no longer in the School of Law.

This paper proceeds in five parts. Part I surveys the current landscape of legal education and notes the need for disruption. In Part II, we describe our own experience with disruptive leadership and the backlash we experienced in response. The characteristics of academia that serve as obstacles to disruptive leadership are then discussed in Part III, which details how tenure, academic freedom, and administrative disinterest create an environment that resists disruption. Next, Part IV examines characteristics unique to law schools that dampen disruption: the American Bar Association's ("ABA") monopoly on law school accreditation and the lack of diversity in legal education. Finally, we conclude by briefly discussing the risks of failing to embrace disruptive leadership in legal education.

\section{LEGAL EDUCATION IS RIPE FOR DISRUPTION}

Legal education is ripe for disruption because the legal profession and law itself are ripe for disruption. The recession that began around $2008 \mathrm{had}$ devastating effects on corporate law firms, which resulted in significant cutbacks and scaled-back law school admissions: Between 2010 and 2015, demand for legal education dropped forty percent. ${ }^{8}$ With rising student debt, the "go to law school to establish yourself in a profession that is secure financially" model has become increasingly untenable, especially for young lawyers emerging from law schools with lower US News \& World Report rankings.

${ }^{7}$ Id.

${ }^{8}$ James Huffman, Law Schools: Reform or Go Bust, NEWSWEEK (Feb. 20, 2015), http://www.newsweek.com/law-schools-reform-or-go-bust-308339. 
Salaries for law school graduates are bifurcated: Graduates from topranked schools make hefty salaries at big firms with corporate clients, while graduates from lower-ranked schools make do. ${ }^{9}$ Increasingly, institutions have well-trained and well-paid lawyers representing them; individuals have no one because even the more modest rates of small firms and solo practitioners are beyond their reach. Rising student debt puts financial pressure on new lawyers to charge higher fees for their services, thereby rendering those services inaccessible to all but the rich or those in acute need. ${ }^{10}$

The crisis in legal education reflects an increasing mismatch between the limited services that the law and lawyers provide and the vast and acute societal needs for legal services. This mismatch is manifested in multiple ways. Perhaps most surprisingly, it is manifested even at the level of sophisticated law firm representation of corporations. Law professor and economist Gillian Hadfield of the University of Toronto describes in Rules for a Flat World: Why Humans Invented Law and How to Reinvent It for a Complex Global Economy how the law and lawyers have not developed to meet the need for complex and adaptive regulation of "flat world" and global industries. ${ }^{11}$ In the face of a fast-paced and interconnected global economy, she writes, "we rely too much on centralized planning and not enough on markets to build the components of our legal infrastructure."

Concurrently, most individuals in the United States cannot afford to retain a lawyer. A recent study by the ABA on the future of legal services concluded that an estimated eighty percent of the poor and those of moderate income lack meaningful access to our justice system and legal services. ${ }^{13}$ The ABA study also found that numerous attorneys, "especially re-

${ }^{9}$ See Catherine Rampell, The Toppling of Top-Tier Lawyer Jobs, N.Y. TIMES (July 16, 2012), https://economix.blogs.nytimes.com/2012/07/16/the-toppling-of-toptier-lawyer-jobs/ (explaining that the top earners find jobs as first-year associates at big law firms while the lower-salary earners typically work for smaller law firms or the government).

${ }^{10}$ See Thomas E. Chase et al., Comm. on Legal Educ. \& Admission to the Bar, LaW SCHOOL DEBT AND tHE PRACTICE OF LAW 2, https://www.nycbar.org/pdf/report/lawSchoolDebt.pdf (last visited Mar. 3, 2019).

${ }^{11}$ See Gillian K. HADFIELd, Rules FOR a Flat World: Why Humans InVENTED LAW AND HOW TO REINVENT IT FOR A COMPLEX GLOBAL ECONOMY 5 (2016).

${ }^{12} I d$. at 199.

${ }^{13}$ Am. Bar Ass'N COMm'N ON the Future of Legal Servs., Report on the Future OF Legal Services in the United States at iii (2016), https://www.americanbar.org/content/dam/aba/images/abanews/2016FLSReport_F NL_WEB.pdf. 
cent law graduates, are unemployed or underemployed despite this significant unmet need for legal services." ${ }^{\prime \prime}$

In addition, law has become increasingly attenuated from justice in the sense of contributing to the creation of "right relationships" between and among people. Because law is inaccessible to most individuals, it is irrelevant to them except as they are subjected to bureaucratic regulation by the government. Law has become a burden rather than a useful tool for people figuring out how to live and work together. ${ }^{15}$ A significant proportion of students come into law school seeking to work for justice, yet law school and the legal profession too often send the message that justice is irrelevant.

Because of this mismatch between what law offers and what people need, nontraditional processes that allow for coordination, collaboration, and conflict engagement and resolution have overtaken courtroom and law office services. ${ }^{16}$ Arbitration, mediation, restorative justice, collaborative governance, LegalZoom, negotiated settlements and regulation, and more were once secondary to litigation and other lawyer-dominated processes. Though the balance has now tipped, the focus of legal education and the legal profession on lawyers obsessively grooms the traditional tail while ignoring the ever-evolving dog.

As a result, legal education is "at [a] crossroads... legal educators should be talking about an entirely new business model." ${ }^{17}$ Law professor William Henderson, who analyzes the legal profession and legal education, concurs: "Legal education and the legal professions are at an inflection point where traditional models of education and practice no longer fit the shifting needs of the market." departing Brooklyn Law Dean Nick Allard described change in the profes-

${ }^{14} \mathrm{Id}$. at 16 .

${ }^{15}$ See Michael Zuckerman, Is There Such a Thing as an Affordable Lawyer?, ATLANTIC (May 30, 2014), https://www.theatlantic.com/business/archive/2014/05/is-there-such-a-thing-as-anaffordable-lawyer/371746/.

${ }^{16}$ See, e.g., Oralandar Brand-Williams, More Disputes in Mich. Settled Through Mediation, DETROIT NEws (Mar. 29, 2018), https://www.detroitnews.com/story/news/local/waynecounty/2018/03/29/mediation/33406027/.

${ }^{17}$ Huffman, supra note 8.

${ }^{18}$ Bill Henderson, The Institute for the Future of Law Practice, LEGAL Evolution (Feb. 11, 2018), https://www.legalevolution.org/2018/02/institute-future-lawpractice-043/. 
sion as "inevitable" and warned that "clinging to the "business as usual" status quo" is not a viable option. ${ }^{19}$

At the same time, Allard characterized the legal profession and legal academia as "always slow and even resistant to adaptation." 20 The ABA study on the future of legal services similarly concludes that the traditional law practice business model, along with the legal profession's resistance to change, hinders innovations that would "provide greater access to, and enhance the delivery of, legal services."21 Hadfield goes further, describing the legal profession as having a monopolistic lock on law. This monopoly includes law schools and legal education, which cling to JD and LLM programs, blinkered from the acute need for law and legal services that surrounds them. ${ }^{22}$

Michele Pistone and Michael Horn of the Christensen Institute for Disruptive Innovation criticize law schools' exclusive focus on the JD. In their report "Disrupting Law Schools," they write:

By fixing their gaze on maintaining prestige in their juris doctor (JD) degree programs, law schools and their administrators run the risk of overlooking the longer-term impact that the disruption of traditional legal services businesses will have on the provision of legal services and, in turn, on law schools themselves...

Pistone and Horn's prescription aligns with access-to-justice advocates: "The roots of disruptive innovation lie in the serving of nonconsumptionareas in a sector where people have no access to the existing offerings because they are too expensive, inconvenient, or complicated to use and therefore the alternative to the innovation is nothing at all." 24

Lawyers need not be the only providers of legal services. Doctors today work alongside not only nurses but other health care professionals with di-

${ }^{19}$ Paul Caron, Allard: The Future of Legal Education, TAXProfBLoG (June 20, 2018), http://taxprof.typepad.com/taxprof_blog/2018/06/allard-the-future-of-thelegal-profession.htm.

${ }^{20} I d$.

${ }^{21}$ AM. BAR ASS'N COMM'N ON THE FUtURE OF LEGAL SERvS., supra note 13.

${ }^{22}$ See Mark A. Cohen, Law Schools Must Restructure. It Won't Be Easy., ForBes (May 15, 2017), https://www.forbes.com/sites/markcohen1/2017/05/15/lawschools-must-restructure-it-wont-be-

easy/\#5e2c4ece3d3f.

${ }^{23}$ Michele R. Pistone \& Michael B. Horn, Disrupting Law School: How DisRuPtive INNOVATION WILL REVOLUTIONIZE THE LEGAL WORLD 2 (2016).

${ }^{24} I d$. 
verse training and diverse skills; these teams extend the ability of the health care system to take care of patient needs. Similarly, with additional legal professionals, the work of lawyers could reach much further and serve many more people than it does at present. There has been a recent uptick in the number of persons taking the $\mathrm{LSAT}^{25}$ and applying to JD programs in law schools. ${ }^{26}$ While this trend lulls law schools back into comfortable reliance on the JD, a few additional lawyers will not meet the pressing and widespread demand for legal services.

\section{THE OPPORTUNITIES AND THE PITFALLS OF DISRUPTIVE LEADERSHIP}

When we arrived at Creighton School of Law, one of us in 2007 and the other in 2011, each of us had been faculty members at other law schools. We saw Creighton's small scale and personal relationships in Nebraska as creating an ideal environment for innovation and for nimble responses to the documented lack of legal services in both urban and rural parts of the state. We were energized by the opportunities presented at a small regional private law school with close ties to the local legal community and the state bar. We were particularly excited by Creighton's Jesuit mission of service to others and its expressed commitment to social justice endeavors to form graduates and benefit the community. A new, yet already nationallyrecognized program in Negotiation and Conflict Resolution provided inhouse expertise in innovative approaches that complement and expand the effectiveness of traditional law.

We soon found ourselves in the middle of comprehensive strategic planning, a dean search, self-study and reaccreditation, and programmatic assessment. Enthusiastic about the school's potential, we carved out time for institutional service to lay the groundwork that would position the School of Law to innovate and adapt to the new world of law and legal practice that we saw emerging. With the downturn in law school admissions and a need for additional revenue to avert damaging budget cuts, we were ready and able to share our experiences from other institutions and strategize about

\footnotetext{
${ }^{25}$ Debra Cassens Weiss, Increase in LSAT Test Takers Seen as Evidence of 'Trump Bump', ABA $\quad$ J. (Nov. 21, 2017), http://www.abajournal.com/news/article/increase_in_lsat_test_takers_is_seen_as_e vidence_of_trump_bump.

${ }^{26}$ Karen Sloan, Number of Law Student Applicants Surges, Especially Among High Scorers, RECORDER (July 30, 2018), https://www.law.com/therecorder/2018/07/30/number-of-law-school-applicantssurges-especially-among-high-scorers/.
} 
new multi-disciplinary and alternative non-JD legal programs. Similarly, along with other colleagues, we embraced assessment of our JD program and the information it could provide to illuminate needs in the curriculum. The arrival of a new outside dean in 2015 added administrative endorsement and support for this evolution, including data-driven decision-making. Other academic units across campus were excited to see new School of Law leadership and vision and sought partnerships in multi-disciplinary offerings involving the law. Alumni were on board as well, demonstrating their support with increased donations.

Within two years, however, a cohort of fellow faculty members, drawn predominantly from the ranks of those with the most seniority, had negatively branded us "reformers" who were seeking to move students away from "real law." This cohort vigorously resisted multi-disciplinary course offerings such as conflict engagement, critical race theory, or the effects of changing national demographics on law. Bar passage rates declined precipitously, and senior faculty blamed the students, all the while resisting programmatic assessment to improve the quality of the education provided. Contradicting the University's own mission, the cohort also opposed efforts to integrate social justice values into the JD curriculum. Overall, our relatively mild exercise of disruptive leadership in responding to fundamental shifts in the legal landscape was met with a level of blowback that neither of us could have imagined.

In the face of this resistance, which escalated into personal attacks and to which a fledgling University administration capitulated, both of us sought and secured other academic appointments. The newly-hired dean was "invited" to move out of the administrative suite and into an office on faculty row after an unexpected sabbatical year-the second time an outside, shortterm dean was ushered out by the School of Law faculty in an eight-year period. The Negotiation and Conflict Resolution Program was transplanted to a Department of Interdisciplinary Studies in the Graduate School and its expertise and vision quarantined from the JD curriculum and students.

\section{ACAdemic Resistance to Change: Tenure, ACADEmic Freedom, AND ADMINISTRATIVE DISINTEREST}

Though legal education in the abstract may be ripe for disruption, disruptive leadership in a real-world law school setting is a tough and potentially perilous road. Legal education is closely tied to the legal profession, and as long as lawyers have a monopoly on law, changes in legal education that respond to broader imperatives will face the challenge of not being "real 
law" because the entry to the legal profession lies exclusively through the straitjacket of the bar exam and admittance to a state bar. Further, placement of legal education in universities subjects it to academic constraints that dampen potential change initiatives.

We see three characteristics of academia in general-characteristics that are not limited to legal academia - that contributed to resistance to our disruptive leadership and that are likely to ground resistance to disruptive changes in legal education generally. The first characteristic is tenure. Academic tenure, intended to protect and encourage open discourse, has the additional effect of protecting entrenched faculty and perpetuating institutional inertia. The most seasoned and senior engineers at Boeing have less job security than the least productive tenured faculty member at an average college or university. Tenure gives faculty members who resist change a powerful and easily wielded weapon: They can choose to "not go gentle into that good night" but "[r]age, rage against the dying of the light."

Tenure can contribute to a vibrant and successful intellectual community. But it is a privilege, and it must be monitored and safeguarded to preserve its intended purpose and prevent its misuse. As it turns out, tenure protects bad behavior by faculty from administrative repercussions as well as preventing bad behavior by administration aimed at faculty. In addition, tenure can be used by university leadership as an excuse for avoiding conflict and disregarding unprofessional, even bullying, ${ }^{28}$ behavior engaged in by tenured faculty members.

The second characteristic, related to the first, is academic freedom. The lofty goal of academic freedom is to ensure the free and fair dissemination of views and ideas. This kind of academic freedom protects faculty members from having their views dictated or suppressed by university admin-

27 Dylan Thomas, Do Not Go Gentle Into That Good Night, ACAD. AM. POETS, https://www.poets.org/poetsorg/poem/do-not-go-gentle-good-night (last visited Mar. 2, 2019).

${ }^{28}$ See Jason B. Jones, Is There A Bully In Your Department?, CHRON. HigheR EDUC. (Mar. 23, 2013), https:/www.chronicle.com/blogs/profhacker/is-there-abully-in-your-department/47809 (explaining that "many higher education institutions will try to cope with bullies by waiting them out or ignoring the problem"). But see, e.g., Katherine Mangan, 'My Fights Are With My Peers': When a Professor Gets Banned for Bullying, CHRON. HigheR EduC. (Oct. 10, 2018), https://www.chronicle.com/article/My-Fights-Are-With-

$\mathrm{My} / 244766$ ?cid=db\&elqTrackId=bc5fb304db4549f880962702c86fe9a0\&elq=8da6 lf927504443a8a0e5255107434ca\&elqaid=20924\&elqat=1\&elqCampaignId=9904 (explaining the consequences of bullying among professors). 
istration. But academic freedom can turn from shield to sword. In a highprofile decision recently, for example, the Wisconsin Supreme Court held that academic freedom protected Marquette University Professor John McAdams's right not only to disagree with a graduate student but also to publish her name and contact information, an implicit invitation to others to join in his condemnation of her. ${ }^{29}$

The claim that academic freedom is being infringed can also be used to challenge administrative efforts to monitor academic quality through program assessment. ${ }^{30}$ Even more troubling, "academic freedom has been claimed as an excuse for the most abusive and uncollegial behaviorshouting at colleagues, publicly berating students or staff members, defaming supervisors or other university administrators, shirking professional duties." ${ }^{31}$

Third, the imperatives of university administration and governing boards focus on raising funds and maintaining tradition rather than on responding innovatively to shifting economic and social dynamics. University presidents spend a substantial portion if not a majority of their time fundraising, ${ }^{32}$ often appealing to alumni, ${ }^{33}$ whose views of the school necessarily look backward rather than forward. ${ }^{34}$ University presidents and provosts may also lack essential knowledge regarding "research on innovation and

${ }^{29}$ Colleen Flaherty, Divided Wisconsin Supreme Court Backs Marquette Faculty Blogger, INSIDE HIGHER EDUC. (July 9, 2018), https://www.insidehighered.com/news/2018/07/09/wisconsin-supreme-court-saysmarquette-must-reinstate-professor-it-wanted-fire.

${ }^{30}$ See Timothy REESE CAIN, NAT'L INST. FOR LEARNING OUTCOMES ASSESSMENT, ASSESSMENT AND ACADEMIC FREEDOM: IN CONCERT, NOT CONFLICT 9-12 (2014) (describing the perceived ways in which academic freedom and program assessment are in tension).

${ }^{31}$ Gary A. Olson, The Limits of Academic Freedom, CHRON. HIGHER EdUC. (Dec. 9 , 2009), https://www.chronicle.com/article/The-Limits-of-AcademicFreedom/49354.

32 Mitchell Wellman, 3 Things College Presidents Spend All Their Time Doing, USA TODAY (Jan. 27, 2017), http://www.usatoday.com/story/college/2017/01/27/3things-college-presidents-spend-all-their-time-doing/37427345.

${ }^{33}$ Rick Seltzer, Giving to Colleges Rises by 6.3\%, INSIDE HiGHER EduC. (Feb. 6, 2018), https://www.insidehighered.com/news/2018/02/06/personal-giving-pushesdonations-colleges-and-universities-new-level-2017.

${ }^{34}$ See Robert M. Diamond, Opinion, Why Colleges Are So Hard to Change, InSIDE

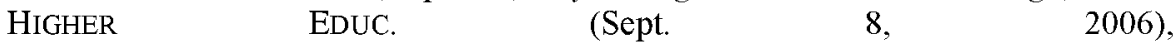
https:/www.insidehighered.com/views/2006/09/08/why-colleges-are-so-hardchange. 
their own role in the process" ${ }^{35}$ as well as essential leadership skills, especially those related to change and conflict.

Though the days of boards of trustees being "clubby men who wrote checks and did little else"36 may be in the past, nonprofit board members at universities are still expected to contribute financially. In their board role, moreover, they lack the accountability for enterprise management that forprofit boards of directors experience by being susceptible to shareholder lawsuits. Nonprofit board members, in contrast, are accountable by law for fiduciary duties owed to the institution, which are enforced only in rare circumstances by the Attorney General of the state in which the organization is chartered. Turning a blind eye to bad behavior by faculty is unlikely to ever result in legal liability for trustees.

\section{LAW SCHOOL EXCEPTIONALISM: MONOPOLY AND GENDER DOMINANCE}

The dynamic between university administrators and law schools is especially likely to be inhospitable to necessary changes. For decades, law schools were cash cows for universities: Large class sizes and minimal hands-on clinical offerings led to law school revenues that supported other academic programs across campuses. ${ }^{37}$ Because of law school financial contributions, university oversight was relatively deferential, and both central office administrators and law faculty grew accustomed to laissez faire management. Add in accreditation of law schools by the ABA, which until very recently did not even require meaningful assessment of JD programs, and you have a recipe for habits of non-accountability. Moreover, university administrators may well be cautious about taking on entrenched and tenured law faculty who as lawyers might be expected to be relatively litigious, as we experienced.

Two additional characteristics of legal education in particular contribute to militant resistance to disruption. The first is the ABA's monopoly on both the practice of law and the accreditation of law schools. According to Professor Henderson, the legal profession is currently challenged by an en-

${ }^{35}$ See id.

${ }^{36}$ Robert Strauss, Expectations Mount for Trustees in Higher Education, N.Y. TIMES (Nov. 4, 2015), https://www.nytimes.com/2015/11/08/giving/expectationsmount-for-trustees-in-higher-education.html.

37 See Megan McArdle, Law School Enrollments are Plummeting. What Happens Next?, DAILY BEAST (Jan. 18, 2013), https://www.thedailybeast.com/law-schoolenrollments-are-plummeting-what-happens-next. 
vironment in which "the cost of traditional legal services is going up, access to legal services is going down, the growth rate of law firms is flat, and lawyers serving ordinary people are struggling to earn a living." ${ }^{38}$ Lawyers, who themselves are JDs and graduated from law schools configured to meet twentieth century needs, are in control of how legal practice is defined and regulated and of setting barriers to entry. Lawyers wield "unauthorized practice of law" sanctions as a protection against competition despite the fact that much of the law that non-lawyers seek to practice is law that lawyers find tedious and unprofitable. ${ }^{39}$

There is little if any professional agitation for transformation of the legal landscape. Legal education and the legal profession consisting exclusively of lawyers are locked in a symbiotic cycle. Change in response to a shift in legal needs requires movement by law schools and the ABA and state supreme courts, which regulate the profession. Successful disruption requires shifts across the board, which means that disruption in one arena alone is likely to be ruthlessly suppressed.

The effects of this monopoly are compounded by a second characteristic of law and legal education: a lack of diversity. Law and legal education today remain highly gendered: Men and traditionally masculine norms permeate the profession and continue to dominate in law schools even as student enrollment approaches gender parity. ${ }^{40}$ The two of us began collaborating as institutional leaders at Creighton as members of the School of Law's Strategic Planning Committee. Both of us had been elected by the faculty. One of us (Nick) was Chair; the other (Palma) was a member who had served on the Committee for a number of years. It was evident that we enjoyed working together and that we were a strong team. After one contentious strategic planning meeting, a very senior (white male) member of the

38 William D. Henderson, State Bar of Cal., Legal Market Landscape REPORT at i (2018), https://taxprof.typepad.com/files/henderson.pdf.

${ }^{39}$ See Roy Strom, California Bar to Consider Changes to Nonlawyer Ownership Rules, AM. LAW. (July 23, 2018), https:/www.law.com/americanlawyer/2018/07/23/california-bar-to-considerchanges-to-non-lawyer-ownership-rules/.

40 See, e.g., Am. Bar Ass'n Comm'n on Women in the Profession, A Current

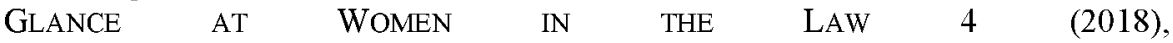
https://www .americanbar.org/content/dam/aba/administrative/women/a-currentglance-at-women-in-the-law-jan-2018.authcheckdam.pdf; Dara Purvis, Female Law Students, Gendered Self-Evaluation, and the Promise of Positive Psychology, 2012 MiCH. ST. L. REV. 1693, 1694 (2012). 
faculty made a point of warning Nick (via another colleague) that Palma was "emasculating" him.

Our working together subverted the School of Law's norm of male dominance,$^{41}$ perpetuated by the standard practice of female colleagues being openly dismissed or talked over in faculty meetings. Research reveals that mixed-gender leadership teams are stronger and more creative than singlegender teams. ${ }^{42}$ Yet a group that has been dominated by a single gender may resist a shift in gender dynamics as well as changes in practice initiated by more diverse decision-makers. ${ }^{43}$ The hostile reactions to our disruptive leadership eventually rose to a level that each of us found to be personally and professionally unacceptable, leading to our respective departures from the School of Law. And yet this unprofessional behavior toward us as colleagues was consistently dismissed as "just the way [so-and-so] is." Boys, apparently, will be boys.

\section{CONCLUSION: THE NON-ETHICS OF NON-DISRUPTION}

Legal education is ripe for disruption, and disruptive leaders can challenge conceptual mindsets constructively, using technology and data analytics to map changing landscapes and reframe conversations about the future. ${ }^{44}$ In a changing world, adaptation allows organizations to not just hang on but to thrive.

41 See Rick Ruggles, Creighton Law School Seeks to Move Past Conflicts That Consultant Says Created 'Toxic' Atmosphere, OMAHA WORLD HERALD (June 12, 2018), https://www.omaha.com/news/education/higher-education/creighton-lawschool-seeks-to-move-past-conflicts-that-consultant/article_72773523-8889-585ea2a7-1d8b912636f4.html (indicating that "Creighton University's law school endured a clash between tradition and change during the 2016-17 school year, and tradition won.").

${ }^{42}$ See Michael Landel, Gender Balance and The Link to Performance, MCKINSEY \& COMPANY (Feb. 2015), https://www.mckinsey .com/featuredinsights/leadership/gender-balance-and-the-link-to-performance.

43 See generally, GABRIELla GuTIÉRREZ Y MUHS ET AL., PRESUMEd INCOMPETENT 1 (2012); see also Kate Manne, Down GiRL: The LogiC of Misogyny 49-50, 64 (2017) ("misogyny primarily targets women because they are women in a man's world").

${ }^{44}$ Rachel Lebeaux, Disruptive Leadership: A Recipe for Success, WALL STREET J. (July 9, 2018), https://deloitte.wsj.com/cio/2018/07/09/disruptive-leadership-arecipe-for-success/. 
University leaders should take important lessons from their for-profit counterparts and think carefully before quashing disruptive leadership when conflict arises. Gravitating to a safe yet misleading return to calm rewards inertia and suppresses forward momentum. Professor Luke Williams of New York University's Stern School of Business sees the attraction of the familiar in many businesses: "There is far too much emphasis in today's organizations on continuity, and far too little on introducing deliberate discontinuity." $" 45$ Nonprofit organizations like law schools and universities should adopt best business practices to invite and support the disruptive leadership necessary for adaptation, especially in changing professional environments. In a changing world, adaptation allows organizations to not just survive but to thrive.

The casualties of law schools hanging on to the familiar are the students - the very people an educational institution exists to serve. Is it ethical for law schools to mindlessly continue to train students for a profession that is shifting under everyone's feet? Is it ethical for the legal profession to wring its hands about "access to justice" while maintaining its protectionist posture? Is it ethical for university administrators to pocket law student tuition dollars knowing that the debt those students incur is buying them an education that is unlikely to render them financially secure? These are the unwelcome questions that disrupters in legal education should be raisingand that law and the legal profession should join in addressing.

${ }^{45} I d$. 